\title{
FBN2 wt Allele
}

National Cancer Institute

\section{Source}

National Cancer Institute. FBN2 wt Allele. NCI Thesaurus. Code C120567.

Human FBN2 wild-type allele is located within 5q23-q31 and is approximately $401 \mathrm{~kb}$ in length. This allele, which encodes fibrillin-2 protein, plays a role in the formation of extracellular microfibrils and elastic fibers. Mutation of the gene is associated with both congenital contractural arachnodactyly and early-onset macular degeneration. 